\title{
A preliminary checklist of vascular plants of Mt. Arayat National Park, Pampanga, Philippines
}

\author{
Marlon dL. Suba ${ }^{1,4^{*}}$, Axel H.Arriolal,2 \& Grecebio Jonathan D. Alejandro',3 \\ ${ }^{1}$ The Graduate School, University of Santo Tomas, España Blvd., Manila 1015, Philippines \\ ${ }^{2}$ Department of Biological Sciences, College of Arts and Sciences, University of the East, 2219, C.M. Recto Ave, Manila, \\ Philippines \\ ${ }^{3}$ College of Science and Research Centre for the Natural \& Applied Sciences, University of Santo Tomas, España Blvd., \\ Manila 1015, Philippines \\ ${ }^{4}$ Department of Biological Sciences, College of Arts and Sciences, Angeles University Foundation, Angeles City, Pampanga \\ 2009, Philippines \\ "Corresponding author, e-mail: suba.marlon@auf.edu.ph
}

\begin{abstract}
The Mt. Arayat National Park (MANP) is one of the oldest national parks and protected areas in the Philippines. However, very few published studies have been carried out despite its speculated high potential of biodiversity. Therefore, this paper intends to provide a preliminary checklist of vascular plants in MANP with emphasis on their conservation status. Several floristic surveys were conducted in the South and North peaks of MANP. A total of 98 species belonging to 92 genera and 43 families were identified. Of them, Leguminosae was the largest family which contributed 10 species, followed by Euphorbiaceae and Moraceae with 7 species each. The most dominated genera were: Ficus with 3 species, and Artocarpus, Litsea, and Macaranga with 2 species each. Based on IUCN criteria and DENR records, a total of 10 species were threatened while only 8 were least concern and the rest were not evaluated. Among those threatened plants, Cycas riuminiana was the most notable due to its endemicity in MANP. The slash-and-burn farming was one the several threats witnessed in the mountain. Thus, this checklist is vital as it provides a scientific information on MANP's plant diversity and distribution which is a useful starting point for further ecological and bio-prospective research in the area.
\end{abstract}

KEYWORDS Biodiversity; Conservation; endemic; Protected area; Threatened plants.

Received 15.01.2019; accepted 14.03.2019; published online 28.03.2019

\section{INTRODUCTION}

Mt. Arayat National Park (MANP) is identified as one of the several areas in the Philippines as a center of biodiversity by the National Biodiversity Strategy and Action Plan (NBSAP) (DENR-UNEP, 1997). This mountain is an isolated and dormant stratovolcano located in the northeastern portion of the province of Pampanga, which covers an aggregate area of 3,715.28 hectares and with the highest elevation of about 1,030 meters (Dagamac et al., 2014). It lies between $15^{\circ} 12^{\prime} 00^{\prime} \mathrm{N}$ latitude and $120^{\circ} 43^{\prime} 59^{\prime \prime}$ 'E longitude. When the National Parks Act (Act No. 3195) was enacted in 1932, MANP became one the oldest national parks and protected areas in the Philippines by the virtue of Proclamation 203 on September 16, 1933 (DENR-PENRO., 2015).

The topography of MANP is rolling to moderately steep in the lower elevations and generally 
steep and rugged in the upper portions. A circular volcanic crater of about 1,200 meters in diameter covers the western part, and a portion of the northern rim has collapsed due to soil erosion (Dagamac et al., 2014). The mountain consists of three peaks; the North peak $\left(15^{\circ} 12^{\prime} 00^{\prime \prime} \mathrm{N}-120^{\circ} 44^{\prime} 00^{\prime \prime} \mathrm{E}\right)$ is where the main summit occurs with its highest elevation of about 1,030 meters via Barangay Ayala, Magalang route, while the South Peak $\left(15^{\circ} 17^{\prime} 35^{\prime \prime} \mathrm{N}-120^{\circ} 76^{\prime} 42^{\prime \prime} \mathrm{E}\right)$ is about 984 meters via Barangay San Juan Banyo, Arayat route and the Pinnacle Peak $\left(15^{\circ} 10^{\prime} 60^{\prime \prime} \mathrm{N}-120^{\circ} 43^{\prime} 59^{\prime \prime} \mathrm{E}\right)$ is about 786 meters, situated between the North and the South peaks. The soils of the park originated from residual soils of basalt, sandstone, volcanic tuff and limestone (Bau \& Knittel, 1993). The area has an annual temperature range of $2231^{\circ} \mathrm{C}$ with an annual rainfall range of 284-1,844 $\mathrm{mm}$. Moreover, the MANP is characterized by a moist tropical climate with a period of high precipitation from May to October and six months of relatively dry period from November to April (Dagamac et al., 2012).

The richness and the various native plants in MANP have been used as sources of building materials, food, ornamentals, and medicine. The present forest types of MANP are characterized by secondary deciduous type of forest, with species of Musa L., Ficus L., and various dipterocarps representing the predominant trees present (Dagamac et al., 2012).

In the Philippines, assessment of plant diversity of different protected areas has already been started in response to the effort of National Integrated Protected Areas System (NIPAS) established in 1992 to sustain biodiversity (La Viñia et al., 2010). To cite a few, the works of Replan \& Malaki (2007), Amoroso et al., (2009), Villegas \& Pollisco (2008), Buot Jr., (2010), Amoroso et al., (2011), Malabrigo Jr., (2013), and Lagbas et al., (2017) have so far published floristic works but no such work was carried out for MANP.

The values of different aspects of this park is now highly realized since the DENR has placed MANP under a Protected Area Suitability Assessment (PASA) to elevate the status of the mountain into a protected landscape (DENR, 2018). Furthermore, the elevation of the area into a protected landscape would be ideal in addressing the need to protect the national park in line with the current situation of human activities in MANP. Once classified as a pro- tected landscape, this will be designated under the new Republic Act No. 11038 or the Expanded National Integrated Protected Areas System (ENipas) Act of 2018. The ENipas provides a congruent interaction of man and land while providing opportunities for public enjoyment through recreation and tourism within the normal lifestyle and economic activity of the area (DENR, 2018). To intensify management program on utilization and conservation of plant diversity in MANP, a checklist of biological diversity is very essential. This will give a baseline information on which action plan can be made. Hence, this study aims to provide a preliminary checklist of vascular plants including their conservation status of each plant of MANP, Pampanga, Philippines.

\section{MATERIAL AND METHODS}

A research ethics was observed by presenting a letter of request and research proposal to the regional office of the DENR at San Fernando City, Pampanga, Philippines to grant a gratuitous permit. A prior informed consent from the leader of the community who lives in the area was also obtained. Trained Forest Guides were provided for assistance by the Provincial Environment and Natural Resources Officer (PENRO) of Pampanga. Since the nature of the research is participatory, the forest guides were compensated and involved during the entire duration of field work.

Several field visits have been made in the North Peak and South Peak during wet season, September 2016, and dry season, April 2017. According to Rathcke \& Lacey (2003), there are correlations between seasonal changes in the physical environment and the simultaneous germination of many species within plant communities. Since the Pinnacle Peak trails are quite dangerous due to its ridgeline, only the North and South Peaks were allowed to be surveyed.

The plant specimens were collected and assessed at the various collecting sites (Fig. 1). Each specimen included information recorded on herbarium collection labels, such as local names, habitat, altitudes, coordinates, etc. Representative specimens collected were pressed, poisoned and mounted as herbarium vouchers using the wet method. Herbarium specimens were labeled and kept at the University of Santo Tomas Herbarium 


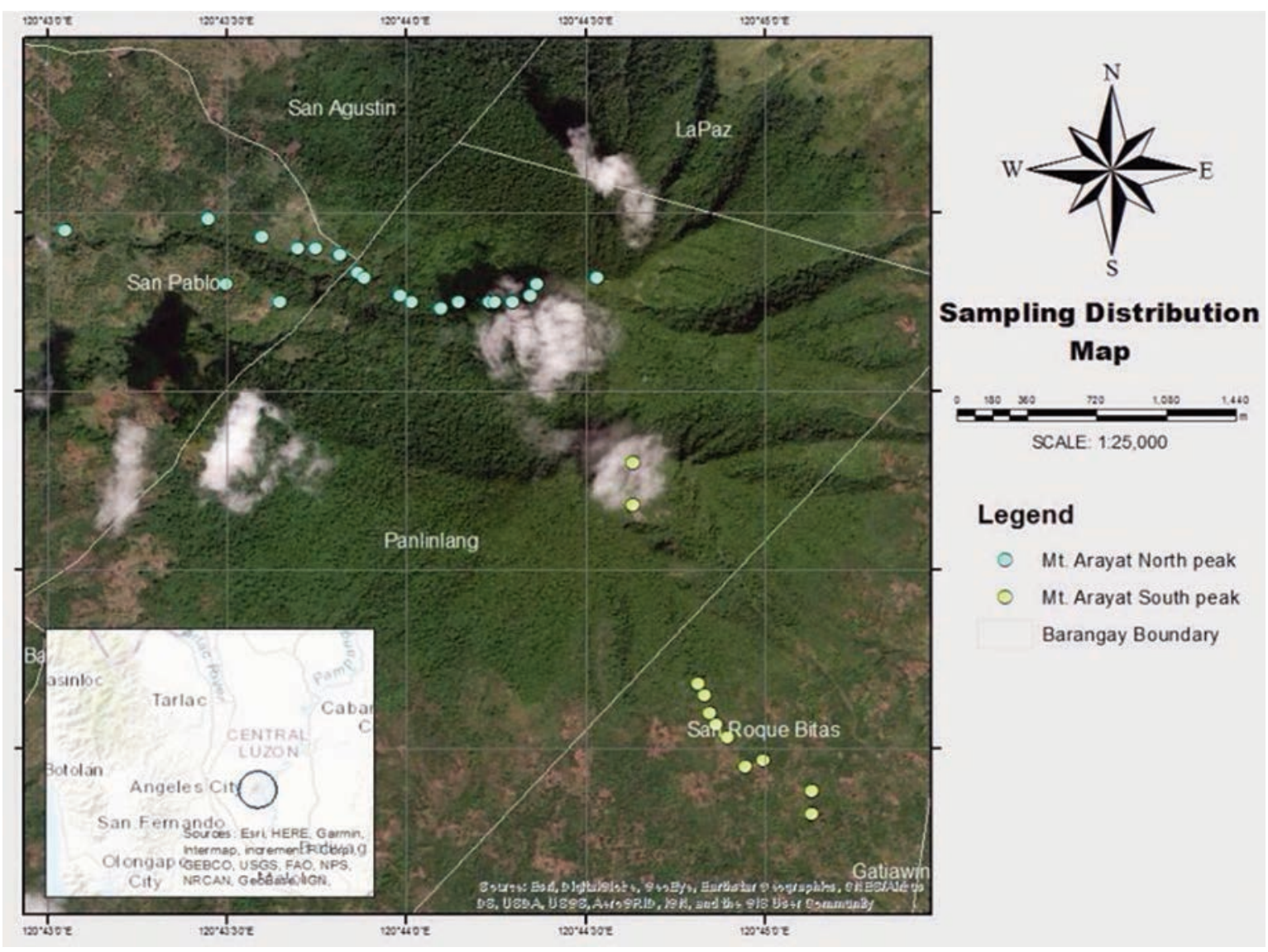

Figure 1. Map of the study sites in MANP. Surveyed areas are marked blue for North peak and green for South peak.

(USTH). All field data gathered were documented in the field notebook and photographs of the different morphological features were used as aid in the succeeding process of identification.

Identification of the collected specimens was conducted at USTH using various literature sources by de Padua \& Bunyapraphatsōn (1999), Madulid (2001), van Valkenburg \& Bunyapraphatsara (2002), Keller (2004), Rummel (2005), and Pancho \& Gruezo (2006), and some open access websites such as Pelser et al., 2018: Co's Digital Flora of the Philippines (www.philippineplants.org), or type specimens from JSTOR (https://plants.jstor.org/) and the Global Biodiversity Information Facility, GBIF (http:// www. gbif.org/).

To validate the scientific names, The Plant List, 2010 (http://www.theplantlist.org/) and Tropicos, 2018 (http:// tropicos.org/) were accessed, While the authentication of unfamiliar plant taxon was identified by the curator at USTH.
To determine the status for each species, whether Critically Endangered (CR), Endangered (EN), Vulnerable (VU), Other Threatened (OT) and Least Concern (LC), the International Union of Conservation of Nature (IUCN) Red List of Threatened Species and the Department of Environment and Natural Resources (DENR) - Administrative Order No. (DAO) 2017-01 aided in categorizing each species. IUCN and Co's Digital Flora (Pelser et al.) of the Philippines were used to identify endemic plants.

\section{RESULTS AND DISCUSSION}

Based on this study, a preliminary list of vascular plant diversity of the MANP was made that includes 98 species under 92 genera and 43 families (Table 1). Of 98 species recorded here, herbs are represented by 16 , shrubs by 29 , trees by 48 , vines 
by 1 , and epiphytes by 4 species (Table 2 ). This represents $0.98 \%$ of 9,995 species of vascular plants in the Philippines (Pelser et al., 2018). The most dominant family in the park was Leguminosae (10) followed by Euphorbiaceae and Moraceae (7) and Lamiceae (5) (Fig. 2). According to Mancera et al. (2013), the dominance of a plant family is not just affected by the distribution agents in the environment. They suggest distribution patterns of other species, which affect, in turn, the conditions of physical surroundings, like the mimosoid stamens and fruits of the Leguminosae family which allow maximum pollination and dispersion (Carlquist 1974; Gillespie et al., 2011). The legume fruits in particular serve as food to a variety of reptiles and mammals in the forest and hence make them efficient seed dispersers.

In the genus, the most represented was Ficus with 3 species, followed by Artocarpus J.R. Forster et G. Forster, Litsea Lam. and Macaranga Thouars with 2 species each. Out of the total 98 species found in the mountain, IUCN Red List and DENR recorded only fifteen (15) and six (6) plant species respectively (Table 3 ). The IUCN Red List (2018) included one (1) EN, six (6) VU, and eight (8) LC while DENR (2017) identified five (5) VU and one (1) OT plant species which make $0.81 \%$ of 984 threatened vascular plants in the Philippines (Co's Digital Flora of the Philippines: Pelser et al., 2018). The OT species refers to a category that is not Critically Endangered, Endangered nor Vulnerable, but is under threat to move to the Vulnerable (DENRDAO, 2017), while the remaining 84 plant species were marked NE. Both IUCN Red list and DENR categorized Reutealis trisperma and Pterocarpus indicus as VU species. On the other hand, Macaranga grandifolia, Swietenia macrophylla, Artocarpus blancoi, and Ficus ulmifolia were reported by IUCN Red List as VU species but not on the list of DENR. Moreover, Cycas riuminiana, Diospyros pyrrhocarpa, Angiopteris palmiformis, and Alpinia elegans are marked as EN, LC, and NE respectively in IUCN Red List. In contrast to DENR, Cycas riuminiana, Diospros pyrrhocarpa, and Alpnia elegans were assessed as VU while Angiopteris palmiformis was labelled as OT. As observed in this study, IUCN and DENR have different categories for a specific species and this is due to their differences in scope or level of assessment (Villanueva \& Buot, 2015). Hence, only
15 of the total 98 plant species were on the records based on the indicators formulated by the IUCN and DENR.

Despite being a protected area, most of the park's large area have long been disturbed and utilized. Based on the records of DENR-PENRO (2015), 738 (20\%) hectares are covered with secondary growth forest, $928(25 \%)$ hectares are plantation, 1,557.47 (42\%) hectares are grassland with patches of reforestation area while the remaining thirteen $13 \%$ hectares are covered with intensive land use of crop production like vegetables and agroforestry species by upland farmers.

In this study, a total of $13(0.30 \%)$ out of 4,359 endemic plants in the Philippines were identified based on IUCN (2018) and Co's Digital Flora of the Philippines (Pelser et al., 2018) data. Some of the threatened species which were restricted in the country were Alpinia elegans, Artocarpus blancoi, and Ficus ulmifolia, while Cycas riuminiana and Macaranga grandifolia were endemic in Luzon. According to Haq et al. (2010), endemic and rare taxa of an area are the most vulnerable because of restricted geographic ranges and specific habitats. Further, other endemic but not threatened species were Croton batangasensis, Lepidopetalum perrottetii, Litsea urdanetensis, Medinilla multiflora, and Micromelum compressum, while Claoxylon albicans, Pandanus exaltatus and Phyllanthus megalanthus were all endemic in the island of Luzon.

Among these endemic plants, Cycas riuminiana is a notable species that was categorized by IUCN Red list as EN and DENR as VU. This species is found in separate localities in lowland mountain forests of Pampanga, Bataan and Batangas in Luzon Island (Madulid \& Agoo, 2009). The largest subpopulation is found in MANP, with smaller subpopulations in the other known localities. Based on DNA analysis, there is no significant genetic diversity among the individuals in the provinces of Pampanga, Bataan, and Batangas, thus suggesting that despite the geographical separation, these individuals belong to only one subpopulation. The estimated population is between 1,000 and 1,500 mature individuals (Agoo et al., 2010). Though MANP is a protected area, this endemic plant is highly threatened. According to Agoo et al. (2010), most of the mature plants of Cycas riuminiana have been removed in MANP due to the development of an exclusive residential resort area. A telecommu- 


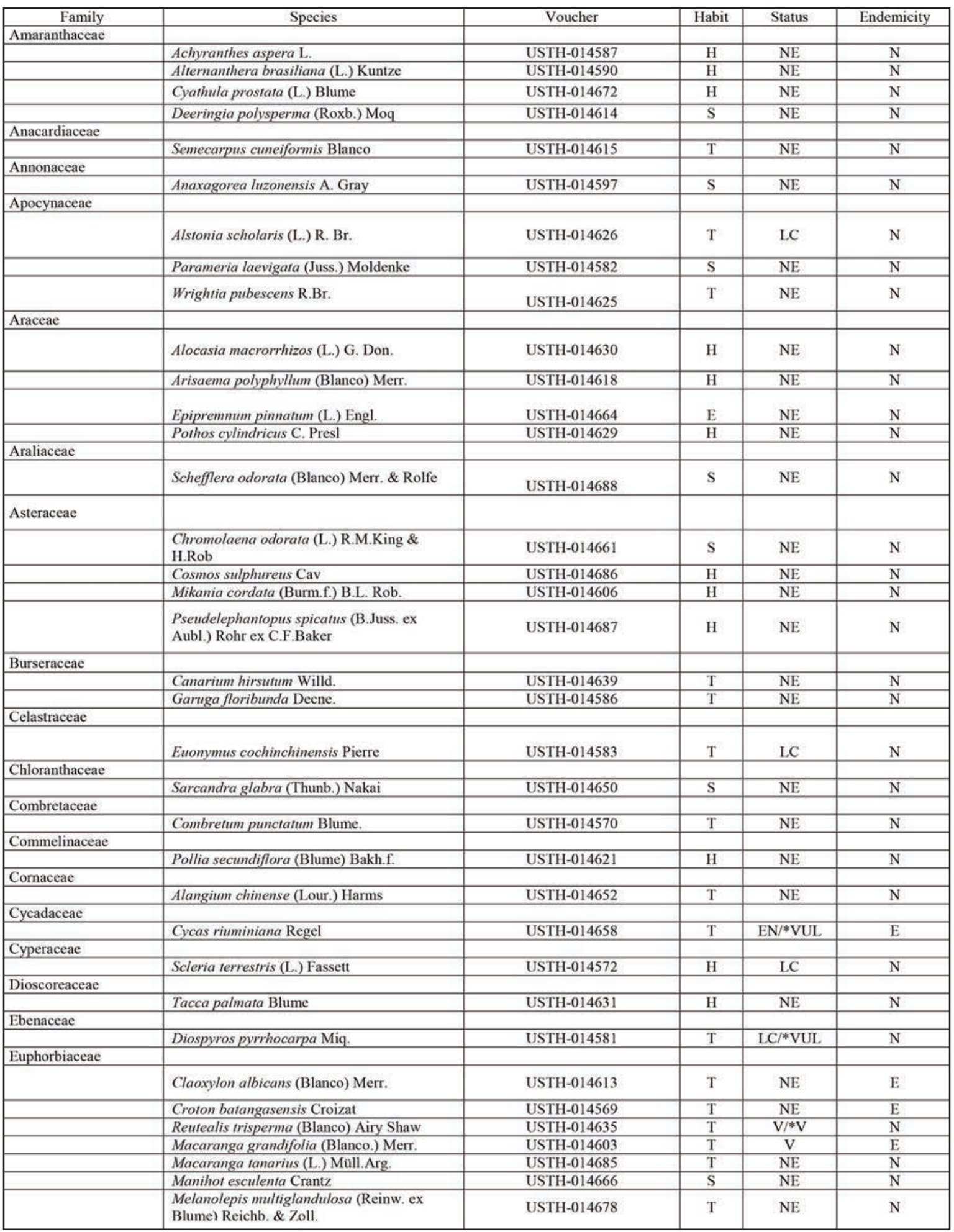

Table 1/1. List of vascular plants identified in MANP. Plant families are alphabetically arranged, followed by species for each family, vouchers, habit $(\mathrm{T}=$ tree, $\mathrm{S}=$ shrub, $\mathrm{H}=$ herb, $\mathrm{V}=$ vine, $\mathrm{E}=$ epiphyte), proposed conservation status based on IUCN Red List of Threatened Species or *DENR Administrative Order 2017-11 (NE = Not Evaluated, DD = Data Deficient, LC = Least Concern, $\mathrm{OT}=$ Other Threatened, $\mathrm{VU}=$ Vulnerable, $\mathrm{EN}=$ Endangered, $\mathrm{CR}=$ Critically Endangered), and endemicity based on IUCN and Co's Digital Flora (E = Philippine endemic, N = non-endemic). All collections done by MDL Suba. 


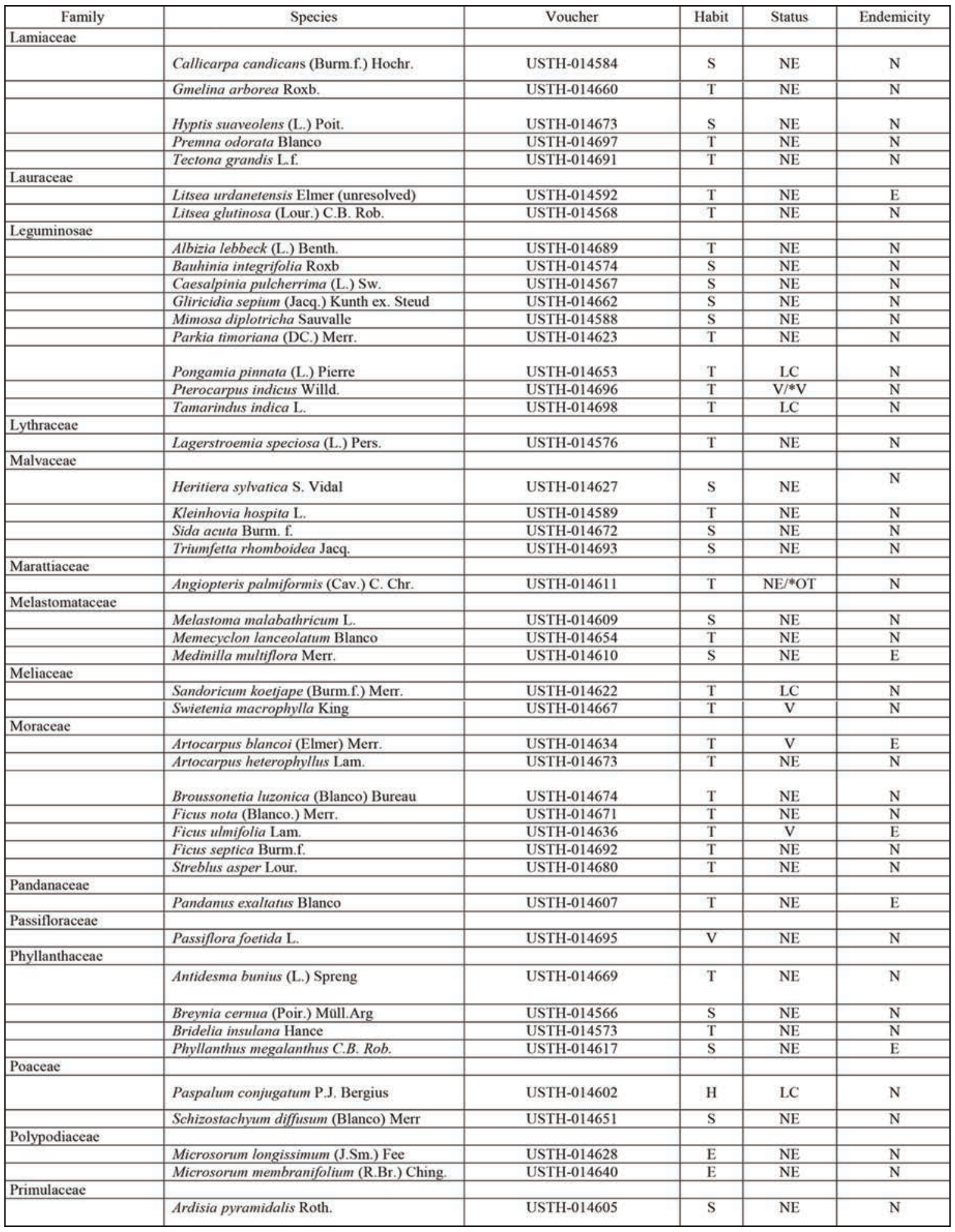

Table 1/2. List of vascular plants identified in MANP. Plant families are alphabetically arranged, followed by species for each family, vouchers, habit $(\mathrm{T}=$ tree, $\mathrm{S}=$ shrub, $\mathrm{H}=$ herb, $\mathrm{V}=$ vine, $\mathrm{E}$ = epiphyte), proposed conservation status based on IUCN Red List of Threatened Species or *DENR Administrative Order 2017-11 (NE = Not Evaluated, DD = Data Deficient, LC = Least Concern, OT $=$ Other Threatened, $\mathrm{VU}=$ Vulnerable, $\mathrm{EN}=$ Endangered, $\mathrm{CR}=$ Critically Endangered), and endemicity based on IUCN and Co's Digital Flora (E = Philippine endemic, N = non-endemic). All collections done by MDL Suba. 


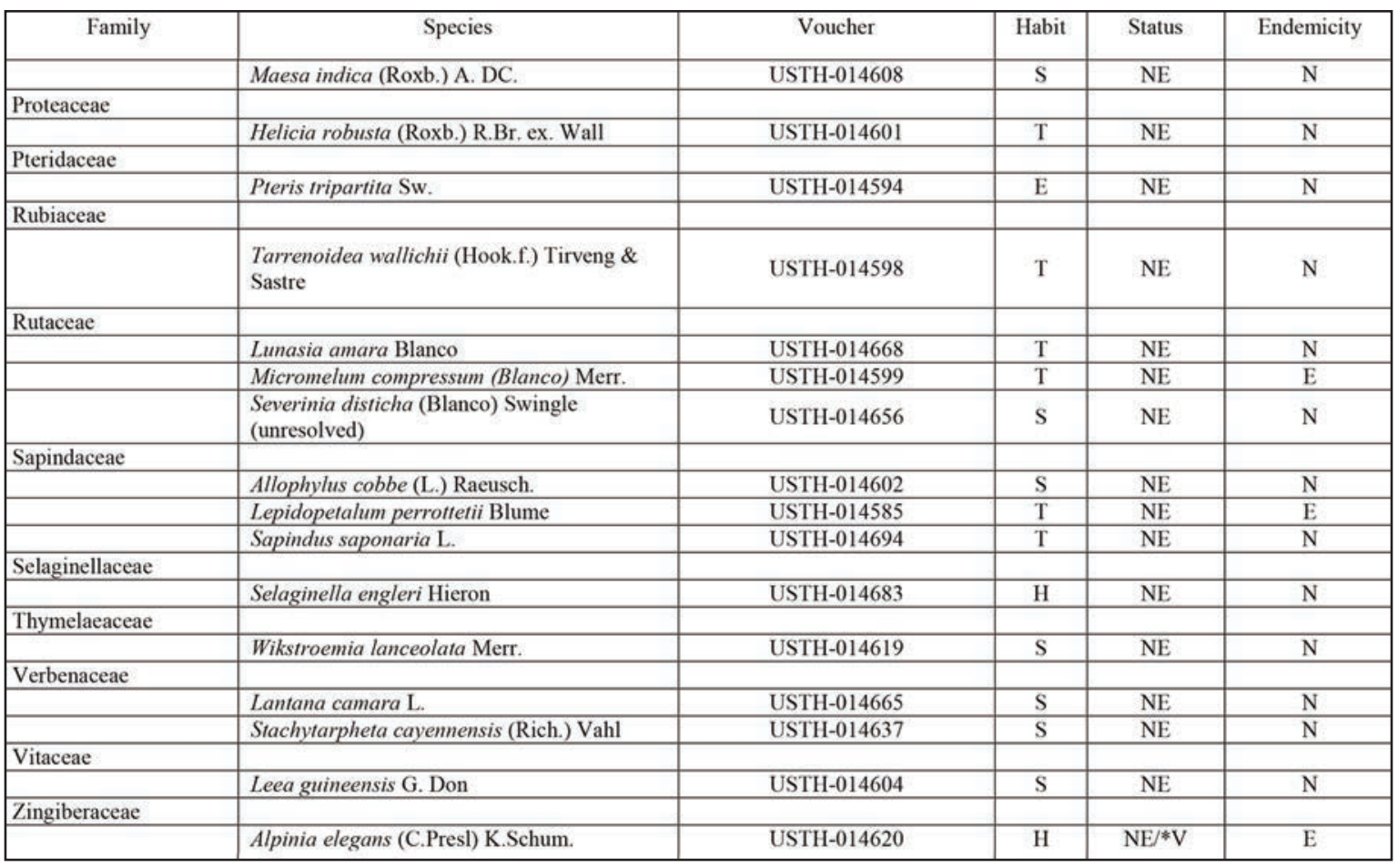

Table 1/3. List of vascular plants identified in MANP. Plant families are alphabetically arranged, followed by species for each family, vouchers, habit ( $\mathrm{T}=$ tree, $\mathrm{S}=$ shrub, $\mathrm{H}=$ herb, $\mathrm{V}=$ vine, $\mathrm{E}=$ epiphyte), proposed conservation status based on IUCN Red List of Threatened Species or *DENR Administrative Order 2017-11 (NE = Not Evaluated, DD = Data Deficient, LC = Least Concern, OT= Other Threatened, VU = Vulnerable, EN = Endangered, $\mathrm{CR}=$ Critically Endangered), and endemicity based on IUCN and Co's Digital Flora (E = Philippine endemic, $\mathrm{N}=$ non-endemic). All collections done by MDL Suba.

nications tower was also built at the peak of the mountain. During the course of field work of this study, other several threats were also observed such as expansion of agricultural lands, which was mostly seen in the South peak, caused by deforestation through slash-and-burn farming. Those trees that burned were used for charcoal making. Other human activities such as irresponsible camping practices of visitors and limited manpower were also noticed.

At present, several projects have been launched to rehabilitate and conserve resources of MANP. The Community Based Program (CBP) is DENR Administrative Order No. 2004-32 which gives opportunities to organize tenured migrant communities and indigenous people to manage, develop, utilize, conserve and protect the resources within the zones of the protected area and consistent buffer zones with the Protected Area Management Plan (PAMP). The Treepreneur Project of Society for the conservation of Philippine wetlands brought in participation of women and children in tree planting activities and maintenance of the assigned plantation areas at MANP were made (SCPW, 2012). Lastly, a new eco-tourist destination will soon rise in Central Luzon. The 10-hectare San Juan Baño recreational facility at the foot of the fabled MANP will undergo major renovation and rehabilitation under a public-private sector partnership scheme proposed by the local government of Arayat (DENR, 2018).

\section{CONCLUSIONS}

The present study provided a preliminary checklist with emphasis on conservation status of vascular plants in MANP, Pampanga, Philippines. The following conclusions are: 98 plant species from 43 families were documented, there is 1 Endangered, 8 Vulnerable and 1 other Threatened plant species; 13 plant species were found endemic, whiT Cycas riuminiana being the most notable; and (3) different threats to biodiversity in MANP were also observed 


\begin{tabular}{|l|c|c|c|}
\hline \multirow{2}{*}{ Plant Groups } & \multicolumn{3}{|c|}{ Total Number of } \\
\cline { 2 - 4 } & Families & Genera & Species \\
\hline Trees & 24 & 43 & 48 \\
\hline Shrubs & 19 & 29 & 29 \\
\hline Herbs & 9 & 16 & 16 \\
\hline Vines & 1 & 1 & 4 \\
\hline Epiphytes & 3 & 3 & 98 \\
\hline & & Total & \multicolumn{2}{|c|}{} \\
\hline
\end{tabular}

Table 2. Taxonomic inventory of vascular plants in MANP.

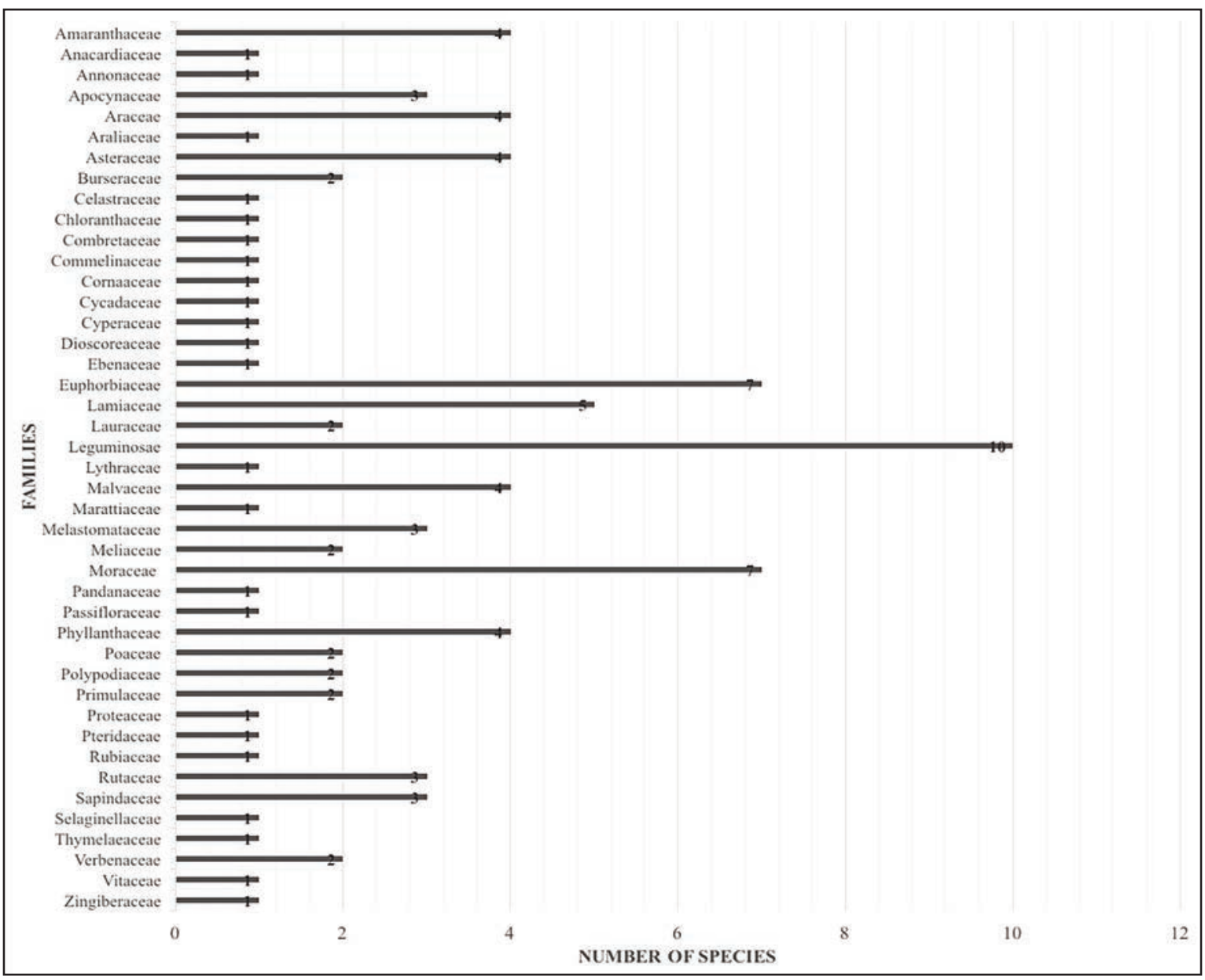

Figure 2. The most common families of vascular plant species recorded in MANP.

during field works. Noteworthy threats are charcoal making at the slopes of the mountain, specifically in South Peak. Charcoal making utilizes slash-andburn techniques that reduce plant cover. The lack of discipline and irresponsible camping practices of visitors, and limited manpower were also observed.
Though there were only few documented plant species under threat, it cannot be denied that biological diversity is rapidly fading in forest, upland, and even in coastal environments in the Philippines and throughout the world. Several management options can be done such as distribution map of threat- 


\begin{tabular}{|c|c|c|c|}
\hline Categories & IUCN & DENR & Total \\
\hline Critically Endangered (CR) & 0 & 0 & 0 \\
\hline Endangered (EN) & 1 & 0 & 1 \\
\hline Vulnerable (VU) & 6 & 5 & $* 8$ \\
\hline Other Threatened (OT) & 0 & 1 & 1 \\
\hline Least Concern (LC) & 8 & 0 & \\
\hline Data deficient (DD) & 0 & 0 & \\
\hline Not evaluated (NE) & 83 & 92 & \\
\hline Total (CR, EN, VU, OT) & & & 10 \\
\hline
\end{tabular}

Table 3. Summary of Threatened and Least Concern vascular plant species found in MANP. *If IUCN or DENR listed same plant species, the plant species is counted as one.

ened plant species. Such map will facilitate accurate location and home range of threatened species in the MANP so that monitoring activities can be carried out easily. In severe cases, ex situ conservation for particular species may be followed to improve their population number. This is a preliminary checklist of vascular plants; the plant diversity is likely to be higher. The inventory of other plants such as bryophytes is also recommended for future studies. Nevertheless, this study has significantly increased the biodiversity knowledge of the park by gaining more detailed insight in the composition of the various vegetation types that can be used to intensify management program on utilization and conservation of MANP.

\section{ACKNOWLEDGEMENTS}

We thank the Research Center for Natural and Applied Sciences, UST, for the herbarium facility. The present work is part of the graduate thesis of the first author in which financial grant has been obtained from the Commission on Higher EducationFaculty Development Program (CHED-FacDev) for the scholarship and research grant.

\section{REFERENCES}

Agoo E.M.G., Madulid D.A., Linis V.C. \& Sambale E., 2010. Cycas riuminiana. The International Union for Conservation of Nature's Red List of Threatened Species. http://www.iucnredlist.org.

Amoroso V.B., Laraga S.H. \& Calzada B.V., 2011. Diversity and assessments of plants in Mt. Kitanglad
Range Natural Park, Bukidnon, Southern Philippines. Gard Bull Singapore, 63: 219-236.

Amoroso V.B., Obsioma L.D., Arlalejo J.B., Aspiras R.A., Capili D.P., Polizon J.J.A. \& Sumile E.B., 2009. Inventory and conservation of endangered, endemic and economically important flora of Hamiguitan Range, Southern Philippines. Blumea, 54: 71-76. https://doi.org/10.3767/000651909X474113

Bau M. \& Knittel U., 1993. Significance of slab-derived partial melts and aqueous fluids for the genesis of tholeiitic and talc-alkaline island-arc basalts: evidence from Mt. Arayat, Philippines. Chemical Geology, 105: 233-251.

Buot I.E. \& Jr., 2010. Conservation status of the commonly collected plant species in selected Philippine mountain ecosystems. The Journal of Tropical Biology, 8: 3-13. https://doi.org/10.1127/0029-5035/ 2013/0142

Dagamac N.H., Stephenson S. \& Dela Cruz T.E., 2014. The occurrence of litter Myxomycetes at different elevations in Mt. Arayat National Park, Pampanga, Philippines. Nova Hedwigia, 98: 187-196.

Dagamac N.H., Stephenson S. \& dela Cruz T.E., 2012. Occurrence, distribution, and diversity of myxomycetes (plasmodial slime molds) along two transects in Mt. Arayat, National Park, Pampanga, Philippines. Mycology, 3: 119-126.

De Padua L.S. \& Bunyapraphatsō N., 1999. Medicinal and poisonous plants. Backhuys Publishers.

DENR Administrative Order, 2017. Updated national list of threatened Philippine plants and their categories. DAO2017-11https://server2.denr.gov.ph/uploads/ rmdd/dao-2017-11.pdf.

DENR-PAWB, 2009. Assessing progress towards the 2010 biodiversity target. The 4th National Report to the Convention on Biological Diversity Republic of the Philippines. www.cbd.int/doc/world/ph/ph-nr-04en.pdf.

DENR-PENRO, 2015. Mt. Arayat National ParkProtected Area Management Plan. Department of Environmentand Natural Resourc Provincial - Environment and Natural Resources Officer. Region III, Pampanga, 1 pp.

DENR-Region III, Central Luzon. 2018. World-class tourist destination to rise in Mt. Arayat National Park. Accessed at: http://r3.denr.gov.ph/.

DENR/UNEP (Department of Environment and Natural Resources/United Nations Environment Program), 1997. Philippine Biodiversity: An assessment and action plan. Bookmark Inc., Makati City, Philippines. $298 \mathrm{pp}$.

GBIF.org, 2018. Global Biodiversity Information Facility. https://www.gbif.org.

Gillespie T.W., Keppel G., Pau S., Price J.P., Jaffre T., Meyer J. \& O’Neill K., 2011. Floristic composition and natural history characteristics of dry forests in the 
Pacific. Pacific Science, 65: 127-141. https://doi.org/ 10.2984/65.2.127

Haq F.H., Alam M. \& Phil M., 2010. Thesis, on Species Diversity of Vascular Plants of Nandiar Khuwar Battagram, $110 \mathrm{pp}$.

IUCN, 2018. The nternational Union for Conservation of Nature Red List of Threatened Species. Version 2018-1. http://www.iucnredlist.org.

JSTOR, 2018. JournalStorage, Accessed https://plants. jstor.org/.

Keller R., 2004. Identification of tropical woody plants in the absence of flowers: A field guide. Birkha"user, Basel, Switzerland.

La Viña A.G.M., Kho J.L. \& Caleda M.J., 2010. Legal Framework for Protected Areas: Philippines. Gland, Switzerland: IUCN. http://cmsdata.iucn.org/downloads/philippines.pdf

Lagbas A., Buot I.E. Jr. \& Mendoza L., 2017. Conservation status of the plant species in selected areas with frequent human activities in Roosevelt Protected Landscape, Bataan, Luzon Island, Philippines. The Thailand Natural History Museum Journal, 10: 79-115.

Madulid D.A. \& Agoo E.M.G., 2009. Taxonomy and conservation of Philippine cycads. Blumea, 54: 99102. https://doi.org/10.3767/000651909X474140

Madulid D.A., 2001. A dictionary of Philippine plant names. 2 volumes. Makati City, Inc., Makati, Philippines.

Malabrigo P.L. Jr., 2013. Vascular flora of the tropical montane forests in Balbalasang-Balbalan National Park, Kalinga province, Northern Luzon, Philippines. Asian Journal of Biodiversity, 4: 1-22. https://doi. org/10.7828/ajob.v4i1.294

Mancera J.P., Ragragio E.M., Sia Su G.L. \& Rubite R.R., 2013. Plant community structure of a secondary forest at Barangay Camias, Porac, Pampanga, The Philippines. Philippine Journal of Science, 142: 135-143.

Pancho J.V. \& Gruezo W.S., 2006. Vascular flora of Mount Makiling and vicinity (Luzon, Philippines),
Part 2. National Academy of Science and Technology (NAST) Philippines, Department of Science and Technology, Bicutan, Taguig City and Institute of Biological Sciences, University of the Philippines Los Baños, College, Laguna, Philippines (Publishers).

Pelser P.B., Barcelona J.F. \& Nickrent D.L. (Eds.), 2018. Co's Digital Flora of the Philippines. http://www. philippineplants.org.

Rathcke B.J. \& Lacey E., 2003. Phenological patterns of terrestrial plants. The Annual Review of Ecology, Evolution and Systematics, 16: 179-214. https://doi. org/10.1146/annurev.es.16.110185.001143

Replan E.L. \& Malaki A.B., 2017. Floral diversity and habitat assessment of Canbantug forest, Argao, Central Visayas, Cebu, Philippines. International Journal of Scientific \& Engineering Research, 8: 775-780.

Rummel D.J., 2005. Useful plants of the Philippines. Quezon City, Philippines: Published and distributed by C\&E Pub.

Society for the conservation of Philippine wetlands (SCPW), 2012. The Treepreneur Project. http:// www.wetlands.ph/projects/treepreneurship/.

The Plant List, 2010. The Plant List: A working list of all plant species. http://www.theplantlist.org/.

Tropicos.org., 2018. Missouri Botanical Garden. http:// www.tropicos.org.

Vanvalkenburg J.L. \& Bunya P.N., 2002. Plant Resource of south East Asia. Medicinals plant. PROSEA, Foundation, Bogor, Indonesia.

Villanueva E.L.C. \& Buot I.E. Jr., 2015. Threatened plant species of Mindoro, Philippines. IAMURE. International Journal of Ecology and Conservation, 14: 168189. https://doi.org/10.7718/ijec.v14i1.901

Villegas K.L. \& Pollisco F.A., 2008. Floral survey of Laiban Sub-Watershed in the Sierra Madre Mountain Range in the Philippines. Journal of Tropical Biology and Conservation, 4: 1-14. 